\title{
WEB TECHNOLOGY AS TOOL TO IMPLEMENT ICT TO MANAGEMENT OF RESEARCH AND DEVELOPMENT IN INSTITUTIONS OF NAES OF UKRAINE
}

\section{ВЕБ-ТЕХНОЛОГІЇ ЯК ЗАСІБ ВПРОВАДЖЕННЯ ІКТ В УПРАВЛІННЯ НАУКОВИМИ ДОСЛІДЖЕННЯМИ В УСТАНОВАХ НАПН УКРАЇНИ}

\begin{abstract}
The article is devoted to the problem of designing the Information system to management of research and development in institutions at the Academy of Educational Sciences of Ukraine on the basis of the Internet, in particular the formulation of requirements for information support of the system and building a conceptual data model. The relevance of the topic of the article is due to the growing need to create information systems aimed at addressing the issue of informatization of management activities in the field of education. The problem of construction of modern information systems in education branch is an actual in modern conditions of information of a society. Today, using paper documentation of research planning processes in NAES of Ukraine, it is impossible to track changes in the information contained in the documents; errors that inevitably occur when creating documents are duplicated in a number of subsequent documents created on the basis of the original, documents and errors are replicated. Implementation of " $R \& D$ management" IS will create a single platform for storing documents on research planning, edit the document in one source with the subsequent reflection of changes in all other documents that reflect this information. Thus, there is a constant updating, updating of information contained in the documents. The use of such an approach to the automation of research research and development management will help increase their efficiency, reduce financial costs and labor costs. Optimization of costs for the implementation and operation of the research and development management information system within the scientific institution can and should be reduced by developing a quality strategy for automation and the implementation of the optimal choice of system. Key words: information system, R\&D management, conceptual model, portal, MS SharePoint 2010, electronic document management
\end{abstract}

Статтю присвячено проблемі проектування інфрормаційної системи менеджменту наукових досліджень у Національній акаде- мії педагогічних наук України на базі мережі Інтернет, зокрема формулюванню вимог до інфрормаційного забезпечення системи та основним аспектам побудови концептуальної моделі даних. Актуальність теми статті зумовлена зростанням потреби у створенні інорормаційних систем, спрямованих на вирішення питання інформатизаціі управлінської діяльності у сфері освіти. Проблема побудови сучасних інорормаційних систем у галузі освіти є актуальною в сучасних умовах інформаційного суспільства. Сьогодні, використовуючи паперове документуванння процесів планування наукових досліджень в НАПН України, неможливо відстежити зміни інфоормації, що міститься в документах; помилки, які неминуче виникають при створенні документів, дублюються в ряді наступних документів, створених на основі оригіналу, тиражування документів та помилок. Упровадження IC «Наукові дослідження» дозволить створити єдину платформу для зберігання документів із планування досліджень, редагування документа в одному джерелі з подальшим відображенням змін у всіх інших документах, що відображають цю інформацію. Таким чином, відбувається постійне оновлення, оновлення інформації, що міститься в документах. Використання такого підходу до автоматизації управління науковими дослідженнями сприятиме підвищенню їх есрективності, скороченню фрінансових витрат та витрат робочого часу. Оптимізація витрат на впровадження та експлуатацію інфрормаційно системи менеджменту наукових досліджень в межах наукової установи можуть $і$ пови нні бути знижені за рахунок розробки якіс ної стратегії автоматизації та здійснення оптимального вибору системи.

Ключові слова: інформаційна система, менеджмент наукових досліджень, концептуальна модель даних, портал, MS SharePoint 2010, електронний документообіс.
Formulation of the problem. To improve management of research and development (R\&D) it needs to implement Information and communications technology (hereinafter ICT) as it is stated in the National program of the Informatization for Education and Science. It is the technological side of R\&D activity so it is the very important as a practical step to administrative reform and modernization of science and education in Ukraine. It also applies to activity of Institutions of National Academy of Educational Sciences of Ukraine (hereinafter NAES of Ukraine), which conduct research on educational and psychological sciences in Ukraine.

The purpose of the article is to analyze the theoretical and methodical base to development and implement ICT to manage R\&D in Institutions of NAES of Ukraine.
Goals and Objectives. Object of research is the implementation ICT to manage R\&D in Institutions of NAES of Ukraine through information system. Subject of research is web technology as tool to project, implement, train and use "R\&D management" IS. Goals of research are development theoretical and methodical base to implement ICT implement ICT to manage R\&D in Institutions of NAES of Ukraine. Objectives of research: to analyze subject area; to analyze webtechnology (standards, tools, architecture, program platforms, communities); to develop model of site for scientific institution of NAES of Ukraine; experimental verification and testing developed model; summarize the results and conclusions.

Analysis of recent research and publications. The analysis of the scientific and pedagogical 
literature on IS building and implementation in educational field shows that a large number of domestic scholars have addressed key issues in this field. Foreign experience of IS development and implementation is outlined in the works of such scientists as K. Lavrischeva, N. Zadorozhna, T. Kuznetsova, S. Tukalo [2; 7]. However, the issue of introduction of electronic document management systems in the activities of scientific institutions in the field of education remains insufficiently studied.

Presentation of the main material. The main activity Institutions of NAES is scientific research. Currently the research management is running through paper documents that are sent in a few copies from Research Institutions to Presidium of NAES. The research management in Research Institutions of NAES is regulated by "Statute about implementation of researches in the National Academy of Pedagogical Sciences of Ukraine" document [3]. This Statute is developed under the laws of Ukraine "On scientific and scientific and technical activity" [5], "About scientific and scientific and technical examination" [6], "About innovative activity" [4], State standard of Ukraine SSTU a 3973-2000 "System of development and imputing of products on a production. Rules of implementation of research works. Generals" [1], Charter of the National Academy of Pedagogical Sciences of Ukraine and other normatively-legal acts that regulate relations in a scientific field. Statute defines the basic principles to manage research in Institutions of NAES and sets general requirements to $R \& D$ : applications, approval, budget, monitoring, accounting, reporting, results assessment and acceptance criteria. The action of Statute spreads to all fundamental and applied researches that are planned and performed in Institutions of NAES of Ukraine by funds of the state budget and due to other sourcing.

To implement ICT to support above processes need to build and deploy appropriative information system. It can be argued that information system up to date is the artifact as result of the ICT implementation in some area. Moreover information system based on web technology is the most appropriate solution for today. So to implement ICT to manage R\&D in Institutions of NAES of Ukraine needs to create and deployment specific information system named it in this article as "R\&D management" IS.

Any IS is aimed at performing two general tasks: providing certain functionality and interaction with the user. Web-based IS are characterized by two parts at the system architecture level: the part of providing functionality, called backend, and the part of providing interaction with the user called frontend. This is due to the distribution of the web system (servers, clients) and corresponds to the position of software engineering, where the terms frontend and backend reflect the separation of tasks between the level of representation and the level of access to data. Based on this approach, design solutions for building IS based on web technologies will be considered at the frontend level, which is represented as a portal or IS site, and the backend level, which covers servers and IS applications.

The software and technology platform for building and maintaining a system of portals is a software and hardware complex that allows you to build and maintain portals for various purposes and architectures and provide the following set of functions: communication support, personalization, profiling, search, security, standard web access to portal, application execution, collaboration, content management, user management, performance control and management, knowledge management. The successful operation of the portal largely depends on the correct choice of software platform, which, in turn, determines the initial requirements for the hardware platform of the portal.

Subject domain of the "R\&D management" IS. "R\&D management" IS Requirements. "R\&D management" IS should support the comfortable environment of collective activity to manage R\&D and effective automated procedures of management documents (forming, access, synchronization of changes and others like that). Thus, "R\&D management" IS belongs to a class of systems of electronic documents management (EDM).

The defined feature of this class is to provide the document management and group work with documents. A management documents requires the specific processing procedures corresponding to the specific document types and tools to support the depository documents. A group work with documents should be determined by politics of permissions and roles of users.

These fundamental requirements for electronic documents management are the basis of design decisions "R\&D management" IS.

A conceptual data model. As a result of the anal$y$ ysis of the existing approaches for construction of the conceptual model of data of "R\&D management" IS" the iterative approach is chosen. Iterative approach is the performance of work in parallel with the continuous analysis of the results and adjustment of previous stages of work. The project in this approach in each phase of development is a repetitive cycle: Planning - Implementation - Verification - Evaluation (plan-do-check-act cycle).

Data structure "R\&D management" IS is defined by a set of fields all above types of R\&D documents. To ensure the partly automatic filling of these documents in "R\&D management" IS need specify a particular set of document fields that describes workflow R\&D. The fields in the documents are filled by users manually, or its value should be chosen from a fixed list, or the system should calculate needed values 
using fields, defined in supporting papers (financial performance, staff list etc.).

It is very important that same fields (hereinafter named common fields) in all R\&D documents should change synchronically.

A list of common fields for all groups of documents formalized and systematized and so that data structure is described in terms of subject domain "R\&D management", which actually represents a conceptual data model.

Development conceptual data model "R\&D management" IS was carried out as follows:

1. Analyze R\&D management in NAES of Ukraine.

2. Compose lists of common fields of the documents, i.e. the same fields that are used not only in one document.

3. Identify fields.

4. Determine which documents are source of each field.

5. Define a set of documents that use each field.

6. Determine and describe a procedure to fill each field.

7. Compose fields lists whose values are fixed and determined the appropriate list.

The conceptual data model "R\&D management" IS developed by this way, is described as table with following column: Document Name, ID (Document Identifier), Responsible (Department Name where document is prepared), Common Fields (it consists of two columns: Field Name and Field ID).

An unique identifier is appropriated every document, he is described the common fields. An identifier has his colour depending on a group.

MS SharePoint as a software platform "R\&D management" IS. As noted above, "R\&D management" IS belongs to a class of systems of EDM. There are different approaches to design systems like this. There is possible to develop software "from scratch", which will require significant as material and intellectual resources, as well as significant cost of time. Another way is to use existing software platform EDM and customize the requirements particular EDM. It requires less material costs and shorter design time, but the cost of competed SED platform is quite high too. Therefore to develop "R\&D management" IS use a compromise approach, namely use software platform that on the one hand provides a basic EDM functions, and the other supports advanced tools and features to develop applications.

Microsoft SharePoint Products and Technologies (hereinafter referred to SharePoint), namely Microsoft Office SharePoint Server 2010, is adopted as "R\&D management" IS platform due to above requirements.

Basic principles of the "R\&D management" IS. "R\&D management" IS supports existing technology of document processing in NAES of Ukraine through Internet portal with access authorized user. Access to portal menus and other functional is available only for registered users who got per-mission by their officials in NAES of Ukraine in view the hierarchy of administrative subordination: Headship, Departments, Research institutions.

Conclusions. "R\&D management" IS is the first stage to create the electronic document management corporate portal of NAES of Ukraine for whole spectrum of functions in document flow.

Further development the "R\&D management" IS consist in expansion of functionality of corporate portal NAES of Ukraine for support of processes of R\&D monitoring. Methodical principles and design decisions of the "R\&D management" can be used for creation of similar systems in establishments which perform R\&D within by funds of the state budget and due to other sourcing.

\section{REFERENCES:}

1. ДСТУ 3973-2000. Система розроблення та поставлення продукції на виробництво. Правила виконання науково-дослідних робіт. Загальні положення. Чинний від 01.07.2001. Київ : Держстандарт України, 2001. 20 с. URL : https://www.dnu. dp.ua/docs/ndc/standarts/Sustema_rozroblennyu_ DSTU 3973-2000.pdf (дата звернення: 16.11.2021).

2. Задорожна Н.Т., Кузнецова Н.В., Лупаренко Л.А. Проектування моделі типового сайту наукової установи. Інформ. технології і засоби навчання. 2014. T. 39, № 1. C. 275-296. DOI : https://doi.org/10.33407/ ittt.v39i1.976.

3. Положення про порядок планування і контролю виконання наукових досліджень у Національній академії педагогічних наук України : затв. Постановою Президії НАПН України від 17.12.2009 № 1-7/12-395. URL : http://umo.edu.ua/polozhennja-porjadok (дата звернення: 16.11.2021).

4. Про інноваційну діяльність : Закон України від 4 лип. 2002 р. № 40-IV. Дата оновлення: 05.12.2012. URL : https://zakon.rada.gov.ua/laws/show/40-15\#top (дата звернення: 16.11.2021).

5. Про наукову і науково-технічну діяльність : Закон України від 26 листоп. 2015 р. № 848-VIII. Дата оновлення: 18.04.2021. URL : https://zakon.rada. gov.ua/laws/show/848-19\#top (дата звернення: 16.11.2021).

6. Про наукову і науково-технічну експертизу : Закон України від 10 лют. 1995 р. № 51/95-ВР. Дата оновлення: 16.10.2020. URL : https://zakon.rada.gov. ua/laws/show/51/95-\%D0\%B2\%D1\%80\#top (дата звернення: 16.11.2021).

7. Zadorozhna N., Petrushko B., Tukalo S. The Information System as a Tool to Manage R\&D at the National Academy of Pedagogical Sciences of Ukraine. ICT in Education, Research and Industrial Applications: Integration, Harmonization and Knowledge Transfer: Proc. of the Intern. Sci. and Practical Conf., Kherson, Ukraine, June 6-10, 2012. p. 82-95. URL : http:// ceur-ws.org/Vol-848/ICTERI-2012-CEUR-WS-paper20-p-82-95.pdf (дата звернення: 16.11.2021). 